\title{
Benthic bacterial production and nutrient sediment-water exchange in sandy North Sea sediments
}

\author{
Fleur C. van Duyl, Wim van Raaphorst, Arjen J. Kop \\ Netherlands Institute for Sea Research (NIOZ), PO Box 59, 1790 AB Den Burg, Texel, The Netherlands
}

\begin{abstract}
The relationship between benthic bacterial production and biomass and sediment-water exchange rates of inorganic nutrients was examined in the North Sea (Dogger Bank region), in summer. The sediments were sandy, poor in organic matter and with low buffering capacities for nutrients. Fluxes of dissolved inorganic $N$ (DIN) and P (DIP) across the sediment-water interface were measured using undisturbed sediment cores. Bacterlal production ( ${ }^{3} \mathrm{H}$-thymidine incorporation method) in the sediment surface layer and bacterial biomass were analysed in the same sediment. By comparison of the benthic activities at 13 stations we assessed significant negative relations between bacterial production and sediment-water fluxes of nutrients. With increasing bacterial production the net efflux of DIN and DIP decreased. Bacternal production was significantly related to bacterial biomass and bacterial biomass was significantly related to chlorophyll a and pheopigment in the sediment, suggesting that enhanced bacterial production rates were associated with input of organic carbon. The observed relationship between bacterial production and nutrient sediment-water exchange could be explained by temporary immobilization of $\mathrm{N}$ and $\mathrm{P}$ in bacterial biomass. It was demonstrated that in response to a short-term sedimentation event, the increase in benthic bacterial biomass (over a $5 \mathrm{~d}$ period) may equal the decrease in sediment-water effluxes of DIN and DIP. Heterotrophic benthic bacteria can apparently act as sinks for $\mathrm{N}$ and $\mathrm{P}$, which only release $\mathrm{N}$ and $\mathrm{P}$ upon death.
\end{abstract}

\section{INTRODUCTION}

The role of bacteria in early nutrient diagenesis is not well established. Microbial reduction of oxygen and other electron acceptors during decomposition of organic matter is a controlling factor in benthic nutrient cycling (Froelich et al. 1979, Bender \& Heggie 1984), while the importance of chemo-autotrophic nitrifiers is also acknowledged (Henriksen \& Kemp 1988). However, the direct relation between benthic nutrient mineralization and heterotrophic bacterial production is less clear (Meyer-Reil et al. 1980, Blackburn 1988). This is due to the scarcity of benthic bacterial production measurements and the fact that those that are available are discussed largely in relation to food chain dynamics (e.g. Alongi \& Hanson 1985, Kemp 1990).

Traditionally, bacteria are regarded as processors of organic matter, releasing mineral nutrients. In this con- cept positive relations are expected between bacterial growth rates (production) and mineral nutrient release. However, from pelagic and laboratory studies increasing evidence has become available that bacteria may act as net consumers of mineral nutrients, rather than as net remineralizers (e.g. Azam et al. 1983, Wheeler \& Kirchman 1986, Bratbak 1987, Martinussen \& Thingstad 1987, Bloem et al. 1988, Jürgens \& Güde 1990). Recently Tupas \& Koike $(1990,1991)$ showed that bacteria first mineralize a considerable part of dissolved organic nitrogen and subsequently assimilate the released $\mathrm{NH}_{4}{ }^{+}$to meet their $\mathrm{N}$ demand. Net regeneration of $\mathrm{P}$ and $\mathrm{N}$ by bacteria probably only occurs when the $\mathrm{C}: \mathrm{N}$ and $\mathrm{C}: \mathrm{P}$ atomic ratios of the substrate are small compared to the relatively invariant ratio in the bacterial biomass of 45:9:1 (Bratbak 1985, Wheeler \& Kirchman 1986, Goldman et al. 1987). Goldman et al. (1987) showed that $N$ regeneration by bacteria does not occur at substrate atomic $\mathrm{C}: \mathrm{N}$ ratios of 10 or more. 
In sediments, organic matter may have larger $\mathrm{C}: \mathrm{N}$ and $C: P$ ratios than the commonly applied Redfield ratios (e.g. Balzer 1984, Klump \& Martens 1987) due to mineral nutrient loss during autolysis of phytoplankton cells and preferential degradation of organic $\mathrm{N}$ and $\mathrm{P}$ compared to organic carbon. With an average $C: N$ :P atomic ratio of the organic matter in the sediment of 125:11:1 (Klump \& Martens 1987), benthic bacteria are probably net $\mathrm{N}$ and $\mathrm{P}$ consumers according to Goldman et al. (1987). Regeneration of $N$ and P may then occur only upon death of the bacteria.

We hypothesize that when bacterial production coincides with net biomass increase, the production may be negatively related to benthic $\mathrm{N}$ and $\mathrm{P}$ regeneration. In poorly buffered sediments the benthic $N$ and $P$ regeneration will be reflected by the sediment-water nutrient fluxes. The hypothesis was tested in North Sea sediments during a cruise in summer 1988. The Dogger Bank region was selected because of its low deposition of degradable organic matter and the low bioturbation activity. The buffering capacity for nutrients was expected to be low in the poor sandy sediments here, so that relations between nutrient fluxes and bacterial production and biomass may show up

\section{MATERIALS AND METHODS}

Study area and sediment collection. The Dogger Bank is a shallow area on the border between the Southern and the Central North Sea (Fig. 1). Depths of the sampling stations ranged from $25 \mathrm{~m}$ at Stn 62 to $89 \mathrm{~m}$ at $\operatorname{Stn}$ 97. The stations were visited during the Window expedition in July-August 1988.

Intact sediment cores were obtained using a modified cylindrical Reineck-type boxcorer (Reineck 1963) with an inner diameter of $31 \mathrm{~cm}$. At each station 2 boxcores were subsampled for bacterial production and biomass (10 acrylic liners with $2.5 \mathrm{~cm}$ i.d.) and for nutrient flux measurements ( 3 to 7 acrylic tubes with $10 \mathrm{~cm}$ i.d.). Part of the nutrient fluxes were measured in whole boxcores. Cramer (1991) analysed the sediment samples for chlorophyll $a$ and pheopigments by the fluorometric method as described in Holm-Hansen et al. (1965). We applied her data collected in the sediment surface layer ( 0 to $5 \mathrm{~mm}$ ). The sediment texture analyses (by laser-spectrometry) and carbon and nitrogen content of sediment samples (by CHN analyser) were determined by Saager et al. (1989) and van Raaphorst et al, (1990). In this study these data were corrected for the differences in carbonate content of the sediment samples.

Bacterial production and biomass. Bacterial production was measured in sediment slurries with [methyl${ }^{3} \mathrm{H}$ ]thymidine. The filter method of Moriarty (1990) and
Moriarty \& Pollard (1990) was used following van Duyl \& Kop (1990). The $5 \mathrm{~mm}$ top layer of the sediment was removed from the liners and pooled. After brief mixing (up to $1 \mathrm{~min}$ ) aliquots of $100 \mu \mathrm{l}$ wet sediment were withdrawn and dispensed into $25 \mu \mathrm{l}$ aqueous solution containing $25 \mu \mathrm{Ci}\left[{ }^{3} \mathrm{H}\right.$ ]thymidine $\left(42 \mathrm{Ci} \mathrm{mmol}{ }^{-1}\right.$, Amersham, $\mathrm{UK})$ and $75 \mu \mathrm{l}$ filtered $(0.2 \mu \mathrm{m})$ seawater with an increasing concentration of unlabelled thymidine. In this way isotope dilution was assessed for each sampling station. Four concentration steps of added thymidine were offered within the range of 2.5 to $32 \mu \mathrm{M}$ with 3 replicates per concentration. In this way up to 12 production replicates and 4 blanks were produced per sampling station. The slurry was incubated for 1 to $2 \mathrm{~h}$, stopped with ethanol $(80 \%)$ and was further processed after 1 to $7 \mathrm{~d}$ of refridgeration at 4 to $7^{\circ} \mathrm{C}$. To assess the period of linear incorporation of ${ }^{3} \mathrm{H}$-thymidine a time series was made at one of the stations ( $\operatorname{Stn} 67$ ).

As thymidine conversion factor we used the value of $1 \times 10^{18}$ cells formed per mol thymidine incorporated in DNA (Bell 1986, Moriarty 1988, Michel \& Bloem 1993). The recovery of DNA was on average $60 \%$ (see van Duyl et al. 1992a for method). Bacterial production rates were therefore corrected. Using the average C:N:P

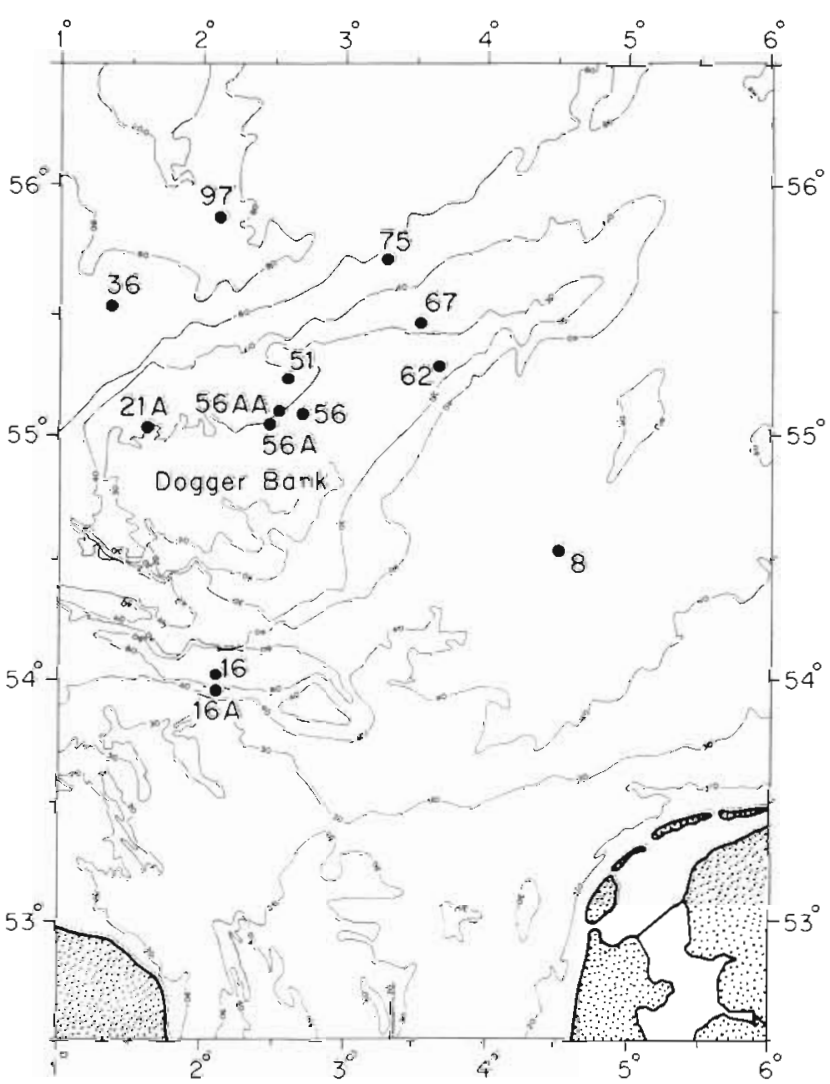

Fig. 1. Bathymetric map of the study area in the North Sea (Dogger Bank region) with the stations visited in the summer of 1988 
ratio of bacterial biomass (45:9:1 atomic ratio; e.g. Goldman et al. 1987) the $\mathrm{N}$ and $\mathrm{P}$ assimilation was estimated on the basis of bacterial $\mathrm{C}$ production measurements.

Acridine orange direct counts were conducted to determine bacterial abundance and size of bacteria and subsequently biomass production, all according to van Duyl \& Kop (1990). One sample per site was analysed. Formaldehyde-fixed bacteria were separated from the sediment by incubation ( $15 \mathrm{~min})$ in a pyrophosphate solution and subsequent sonification, and stained in acridine orange. Bacteria were sized and counted under an epifluorescence microscope (1250x) on $0.2 \mu \mathrm{m}$ Nuclepore filters, prestained in irgalan black. The carbon conversion factor used, was $2.2 \times$ $10^{-10} \mathrm{mg} \mathrm{C} \mu \mathrm{m}^{-3}$ (Bratbak \& Dundas 1984).

Nutrient fluxes. The benthic mineral nutrient flux data and the data on oxygen penetration depths applied in this paper were published in van Raaphorst et al. (1990). Sediment-water fluxes were estimated in 2 different ways. In the first, the fluxes were calculated from the difference between the concentrations in the benthic chambers at the start and the end of the benthic oxygen uptake measurements (van Raaphorst et al. 1990, Cramer 1991). Since this procedure involves the subtraction of only 2 concentrations for every flux estimate, it is not very accurate, particularly when these concentrations do not differ much. In the second method, 3 to 7 replicate cores $(10 \mathrm{~cm}$ i.d.) were placed at in situ temperature $\pm 2{ }^{\circ} \mathrm{C}$, while the overlying water $(750 \mathrm{ml})$ was kept saturated with respect to $\mathrm{O}_{2}$ by continuously bubbling air. In this way, turbulence was introduced in the water column, just below the level where visible suspension of bottom material occurred. During the incubation (ca 40 h) 6 to 9 samples of the overlying water were taken at regular intervals. Although the 2 techniques differ substantially, results of the first were usually within the range of values obtained by the second method. The sediment-water exchange rates were obtained from the slope of the line passing through the nutrient concentrations of these samples. For the equations relevant to the estimation of nutrient fluxes we refer to van Raaphorst et al. (1990).

Nutrients were determined on a Technicon TRAACS 800 auto-analyzer. Phosphate and nitrate were determined according to the procedures outlined by Strickland \& Parsons (1972), and ammonium following the phenol-hypochlorite method (Helder \& de Vries 1979).

\section{RESULTS}

\section{Study area}

All stations in the Dogger Bank region had sandy sediments with median grain sizes between 100 and
$200 \mu \mathrm{m}$, the coarsest sediments being found at the stations on the bank. The organic $\mathrm{C}$ and $\mathrm{N}$ contents were 0.13 to $0.52 \%$ and 0.01 to $0.15 \%$ of dry sediment, respectively. During the expedition (July-August 1988) the water column off the bank was temperature stratified, whereas that on the bank proper was well mixed.

\section{Bacterial production and biomass}

The incorporation of thymidine was linear with time for at least $3 \mathrm{~h}$ as shown by the time course in Fig. 2. The degree of participation of the ${ }^{3} \mathrm{H}$-thymidine in the production assays ranged from 6 to $59 \%$ in the Dogger Bank region, with diluting pools equivalent to 0.34 to $8.03 \mathrm{nmol}(100 \mu \mathrm{l} \text { wet sediment })^{-1}$. Rates per station were corrected for respective isotope dilution. The results of bacterial biomass and bacterial production measurements are listed in Table 1. The bacterial biomass in the upper $5 \mathrm{~mm}$ varied between 120 and $434 \mathrm{mg} \mathrm{C} \mathrm{m}^{-2}$. The average biovolume per bacterium ranged from 0.13 to $0.19 \mu^{3} \mathrm{cell}^{-1}$ (not shown). Bacterial production ranged from $20( \pm 3)$ to $143( \pm 48) \mathrm{mg} \mathrm{C} \mathrm{m} \mathrm{m}^{-2} \mathrm{~d}^{-1}$ in the upper $5 \mathrm{~mm}$ of the sediment. On the basis of a $C: N: P$ ratio of $45: 9: 1$ for bacterial biomass the $\mathrm{N}$ and $\mathrm{P}$ incorporation rates were estimated.

A significant correlation (Fig. 3) was found between bacterial production and biomass (Spearman rank correlation, $r_{5}=0.61, n=11, p<0.05$ ) if Stns $16 a$ and 97 were excluded. Some characteristics of these stations suggest that they may be different from the others. The mean grain size of the sediment at Stn 97 was lower

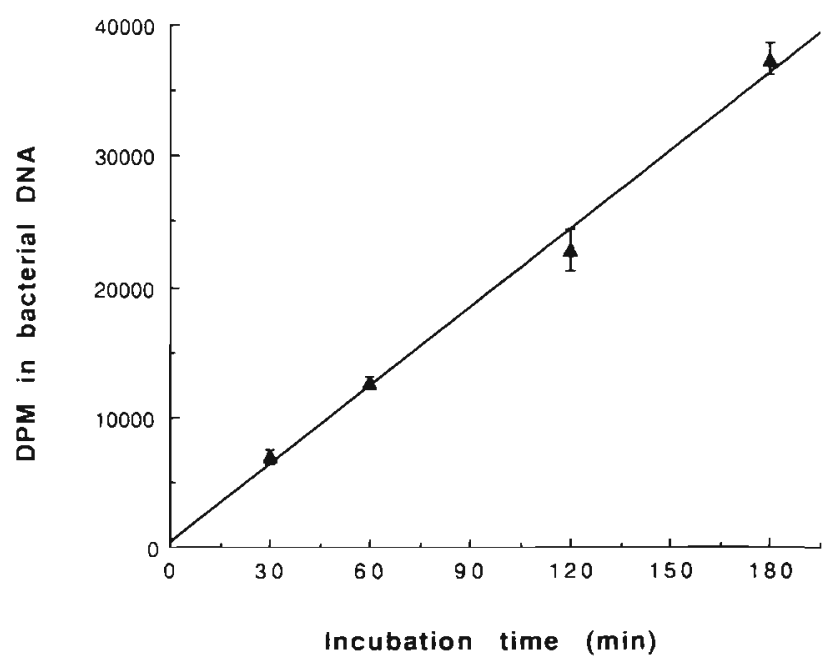

Fig. 2. Time course of ${ }^{3} \mathrm{H}$-thymidine incorporation into bacterial DNA expressed in disintegrations per minute (DPM) in the sediment surface layer $(0$ to $5 \mathrm{~mm})$ at $S t n 67$ at in situ temperature 
Table 1. Site characteristics (depth and temperature) and benthic bacterial biomass and bacterial production/assimilation of $C, N$ and $P$ in the $5 \mathrm{~mm}$ top layer of the sediment for the 13 stations

\begin{tabular}{|c|c|c|c|c|c|c|c|c|}
\hline \multirow[t]{2}{*}{ Stn } & \multirow{2}{*}{$\begin{array}{l}\text { Depth } \\
(\mathrm{m})\end{array}$} & \multirow{2}{*}{$\begin{array}{c}\text { Temperature } \\
\left({ }^{\circ} \mathrm{C}\right)\end{array}$} & \multirow{2}{*}{$\begin{array}{c}\text { Bacterial } \\
\text { biomass } \\
\left(\mathrm{mg} \mathrm{C} \mathrm{m}^{-2}\right)\end{array}$} & \multirow[b]{2}{*}{$\left(m g m^{-2} d^{-1}\right)$} & \multirow[b]{2}{*}{$\mathrm{SE}$} & \multicolumn{2}{|c|}{ - Bacterial production } & \multirow[b]{2}{*}{$\begin{array}{l}\text { P assimilation } \\
\left(\mathrm{mmol} \mathrm{m}^{-2} \mathrm{~d}^{-1}\right)\end{array}$} \\
\hline & & & & & & $\begin{array}{l}\text { Cassimilation } \\
\left(\mathrm{mmol} \mathrm{m}^{-2} \mathrm{~d}^{-1}\right)\end{array}$ & 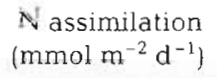 & \\
\hline 8 & 47 & 8.5 & 245 & 89 & 35 & 7.42 & 1.48 & 0.16 \\
\hline 16 & 70 & 11.0 & 274 & 143 & 48 & 11.92 & 2.38 & 0.26 \\
\hline $16 a$ & 51 & 13.0 & 434 & 20 & 3 & 1.67 & 0.33 & 0.04 \\
\hline $21 a$ & 28 & 14.0 & 182 & 35 & 8 & 2.92 & 0.58 & 0.06 \\
\hline 36 & 68 & 6.8 & 222 & 107 & 36 & 8.92 & 1.78 & 0.20 \\
\hline 51 & 37 & 9.7 & 238 & 72 & 28 & 6.00 & 1.20 & 0.13 \\
\hline 56 & 25 & 13.7 & 142 & 111 & 29 & 9.25 & 1.85 & 0.21 \\
\hline $56 a$ & 29 & 13.0 & 120 & 37 & 14 & 3.08 & 0.62 & 0.07 \\
\hline $56 \mathrm{aa}$ & 31 & 13.0 & 148 & 63 & 63 & 5.25 & 1.05 & 0.12 \\
\hline 62 & 25 & 14.5 & 311 & 133 & 32 & 11.08 & 2.22 & 0.25 \\
\hline 67 & 33 & 13.2 & 238 & 108 & 10 & 9.00 & 1.80 & 0.20 \\
\hline 75 & 49 & 7.6 & 146 & 70 & 13 & 5.83 & 1.17 & 0.13 \\
\hline 97 & 89 & 6.6 & 403 & 88 & 26 & 7.33 & 1.47 & 0.16 \\
\hline
\end{tabular}

$(96 \mu \mathrm{m})$ and the $C$ content higher $(0.52 \%)$ than at the other stations (mean grain sizes 128 to $213 \mu \mathrm{m}_{\mathrm{i}} \mathrm{C}$ content 0.13 to $0.39 \%$ ). This is possibly related to the relatively high bacterial biomass at this station. Stn 16 a was an unusual station with respect to inorganic nutrient profiles (van Raaphorst et al. 1990). Signs of physical disturbance of the sediment surface as a result of surface transport of sediment down the slope were present.

The chlorophyll $a$ and pheopigment contents of the sediments at the different stations were 0.2 to 1.5 and 0.7 to $5.5 \mu \mathrm{g} \mathrm{g}^{-1}$ dry sediment, respectively. The pheopigment content of the sediment showed a significant relation to the water depth $\left(r_{S}=0.79, p<0.01, n=13\right)$. Significant correlations were also found between

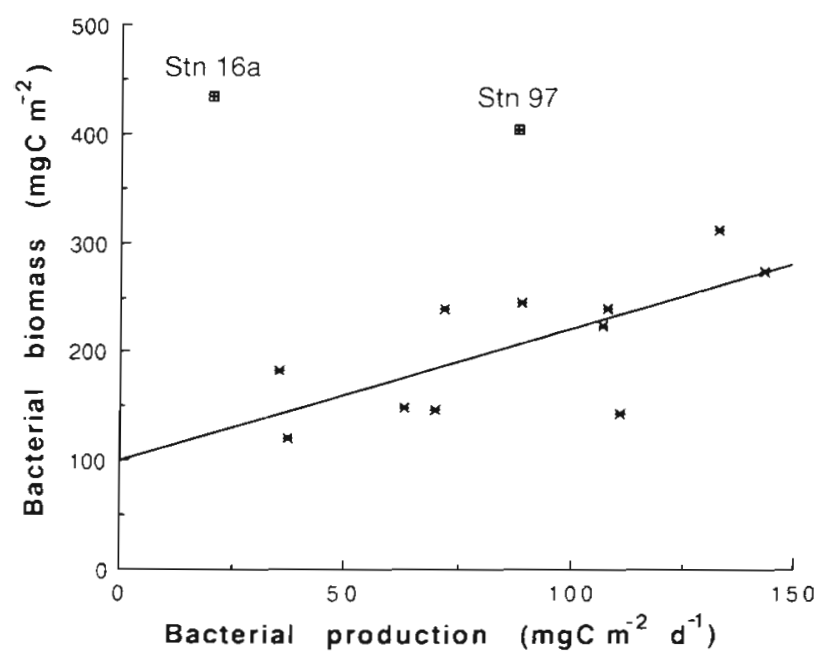

Fig. 3. Relation between benthic bacterial biomass and benthic bacterial production in the $5 \mathrm{~mm}$ top layer of the sediment. benthic bacterial biomass and chlorophyll $a$, and pheopigment content (Table 2). Bacterial production and bacterial biomass were not significantly related to any of the other sediment characteristics listed in Table 2. The sediment-water exchange rates of DIN and DIP were not related to any of the abiotic sediment characteristics in Table 2.

\section{Nutrient fluxes and relations with bacterial production and biomass}

At most stations the DIN and DIP fluxes were directed towards the water column (Table 3 ), but at some stations a net uptake of $\mathrm{NH}_{4}^{+}$and/or $\mathrm{PO}_{4}{ }^{3-}$ by the sediments was found. Benthic $\mathrm{NH}_{4}{ }^{+}$fluxes ranged from $-2( \pm 16)$ to $+745( \pm 215) \mu \mathrm{mol} \mathrm{m} \mathrm{m}^{-2} \mathrm{~d}^{-1}$, those of $\mathrm{NO}_{3}^{-}$ from $73( \pm 23)$ to $322( \pm 30) \mu \mathrm{mol} \mathrm{m} \mathrm{m}^{-2} \mathrm{~d}^{-1}$ and those of $\mathrm{PO}_{4}{ }^{3-}$ from $-6( \pm 7)$ to $+115( \pm 31) \mu \mathrm{mol} \mathrm{m} \mathrm{m}^{-2} \mathrm{~d}^{-1}$. The large standard deviations were mainly caused by coreto-core variations (van Raaphorst et al. 1990). The range in the sediment water efflux of DIN and DIP was smaller (ca 2-fold) than the $N$ and $P$ assimilation by bacteria (comparison of Tables $1 \& 3$ ).

Phosphate sediment-water exchange showed a significant linear covariation with sediment-water exchange of the nitrogen compounds, most strongly with the total DIN flux $\left(r_{\mathrm{s}}=0.92, p<0.01 ;\right.$ Fig. 4). The depth profiles of the concentrations of $\mathrm{NH}_{4}{ }^{+}, \mathrm{NO}_{3}-\mathrm{PO}_{4}{ }^{3-}$ in interstitial water were reported by van Raphorst et al. (1990). Concentrations in the upper $5 \mathrm{~mm}$ of the sediment ranged from 3 to $60 \mu \mathrm{M}\left(\mathrm{NH}_{4}{ }^{-}\right), 9$ to $45 \mu \mathrm{M}$ $\left(\mathrm{NO}_{3}{ }^{-}\right)$and 1.0 to $8.6 \mu \mathrm{M}\left(\mathrm{PO}_{4}{ }^{3-}\right)$ for the 13 stations. Significant correlations between bacterial production, biomass and the respective nutrient concentrations were not found. 
Table 2. Overview of the Spearman rank analyses conducted between sediment and site characteristics on the one hand and benthic bacterial biomass, benthic bacterial production, DIN and DIP sediment-water fluxes on the other hand. ns: not significant

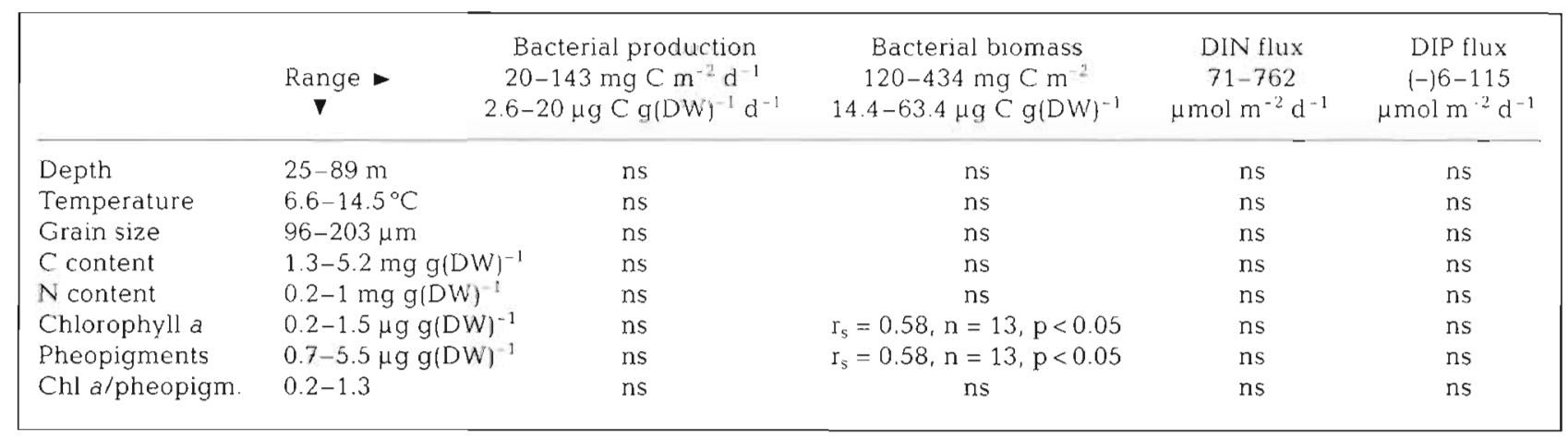

Significant negative correlations were, however, found between bacterial production and the sedimentwater DIN and DIP fluxes (Figs. $5 \& 6$ ), based on Spearman rank correlation and ANOVA tests. The Spearman rank correlation coefficients were $r_{s}=-0.66, p<0.02$ $\left(\mathrm{NH}_{4}{ }^{+}+\mathrm{NO}_{3}{ }^{-}\right), \mathrm{r}_{\mathrm{s}}=-0.58, \mathrm{p}<0.05\left(\mathrm{NH}_{4}{ }^{+}\right)$, and $\mathrm{r}_{\mathrm{s}}=-0.83$, $\mathrm{p}<0.01\left(\mathrm{PO}_{4}{ }^{3-}\right) ; \mathrm{n}=13$ in all cases. Table 4 shows the results of the analysis of variance (ANOVA) with sediment-water exchanges of DIN and DIP as dependent variates, and bacterial production and biomass as independent variates. A linear relation was assumed between the sediment-water fluxes of DIN and DIP and the bacterial variables. The strong negative relation between benthic bacterial production and the inorganic $\mathrm{N}$, P fluxes indicates that benthic nutrient regeneration to the water column was least at high, and greatest at low, bacterial production in the oxic upper $5 \mathrm{~mm}$ of the sediments. At most stations the thickness of the oxic zone was more than $5 \mathrm{~mm}$ (Table 3 ). Consequently, the obtained relations between bacterial production and the nutrient fluxes may be partly misleading. Therefore we

Table 3. Sediment-water exchange of inorganic nitrogen DIN $\left(\mathrm{NO}_{3}{ }^{-}\right.$and $\left.\mathrm{NH}_{4}{ }^{+}\right)$and DIP $\left(\mathrm{PO}_{4}{ }^{3}\right)$ and oxygen penetration depth in the sediment for the 13 stations

\begin{tabular}{|ccrcrc|}
\hline Stn & $\begin{array}{c}\text { DIN flux } \\
\left(\mu \mathrm{mol} \mathrm{m}^{-2} \mathrm{~d}^{-1}\right)\end{array}$ & SD & $\begin{array}{c}\text { DIP flux } \\
\left(\mu \mathrm{mol} \mathrm{m}^{-2} \mathrm{~d}^{-1}\right)\end{array}$ & $\mathrm{SD}$ & $\begin{array}{c}\text { O } 2 \text { penetra- } \\
\text { tion depth (mm) }\end{array}$ \\
\hline 8 & 544 & 252 & 38 & 5 & 7.5 \\
16 & 170 & 49 & -2 & 11 & 12 \\
$16 \mathrm{a}$ & 727 & 30 & 115 & 31 & 4.5 \\
$21 \mathrm{a}$ & 951 & 331 & 104 & 94 & 4 \\
36 & 185 & 72 & 4 & 2 & 12 \\
51 & 301 & 405 & 19 & 27 & 7 \\
56 & 290 & 49 & 6 & 20 & 10 \\
$56 \mathrm{a}$ & 762 & 93 & 58 & 0 & 4 \\
$56 \mathrm{a} a$ & 280 & 35 & 30 & 4 & \\
62 & 71 & 39 & -6 & 3 & 11 \\
67 & 104 & 94 & -6 & 7 & 15 \\
75 & 110 & 101 & 3 & 16 & 20 \\
97 & 157 & 97 & 12 & 18 & 10 \\
\hline
\end{tabular}

normalized the bacterial production by multiplying it by $X_{\mathrm{n}} / 5\left(X_{\mathrm{n}}\right.$ is oxygen penetration depth in $\left.\mathrm{mm}\right)$. This resulted in slightly stronger negative relations for the $\mathrm{NH}_{4}{ }^{+}$and $\mathrm{NO}_{3}^{-}$sediment-water flux, and slightly weaker relations (but still significant) for the DIN and DIP $\left(\mathrm{PO}_{4}{ }^{3-}\right)$ fluxes with bacterial production: $\mathrm{r}_{\mathrm{s}}=-0.63$, $0.02<\mathrm{p}<0.05\left(\mathrm{NH}_{4}^{+}+\mathrm{NO}_{3}^{-}\right), \mathrm{r}_{\mathrm{s}}=-0.64, \mathrm{p}<0.05\left(\mathrm{NH}_{4}^{+}\right)$, $\mathrm{I}_{\mathrm{s}}=-0.58, \mathrm{p}<0.05\left(\mathrm{NO}_{3}{ }^{-}\right)$and $\mathrm{r}_{\mathrm{S}}=-0.82, \mathrm{p}<0.01\left(\mathrm{PO}_{4}{ }^{3-}\right)$; $\mathrm{n}=12$ in all cases. Considering these small differences we used the actual measured bacterial production rates ( 0 to $5 \mathrm{~mm}$ ) in the interpretation.

\section{DISCUSSION}

The source and/or sink function of heterotrophic microorganisms for nutrients has often been invoked to explain patterns in sediment-water exchange of nutrients (e.g. Rutgers van der Loeff 1980, Garber 1984, Klump \& Martens 1987, Simon 1988). Direct evidence for relations between these variables is lacking in marine sediments. Microbial activity measurements in sediments are scarce. Moreover, relations are often masked by a high buffering capacity in sediments with a relatively high organic content.

In the Dogger Bank region the sediments are poor in organic matter, poor in macrozoobenthos, low in benthic activity and well oxygenated (van Raaphorst et al. 1990, Cramer 1991). The significant relationship between sediment water exchange of $\mathrm{PO}_{4}{ }^{3-}$ and DIN in an N:P ratio approaching the ratio of degradable organic matter in sediments (e.g. Balzer 1984, Klump \& Martens 1987) emphasizes that the differential sorption capacities for $N$ and $P$ in the sediments involved were low. Van Raaphorst et al. (1990) concluded, on the basis of porewater data, 


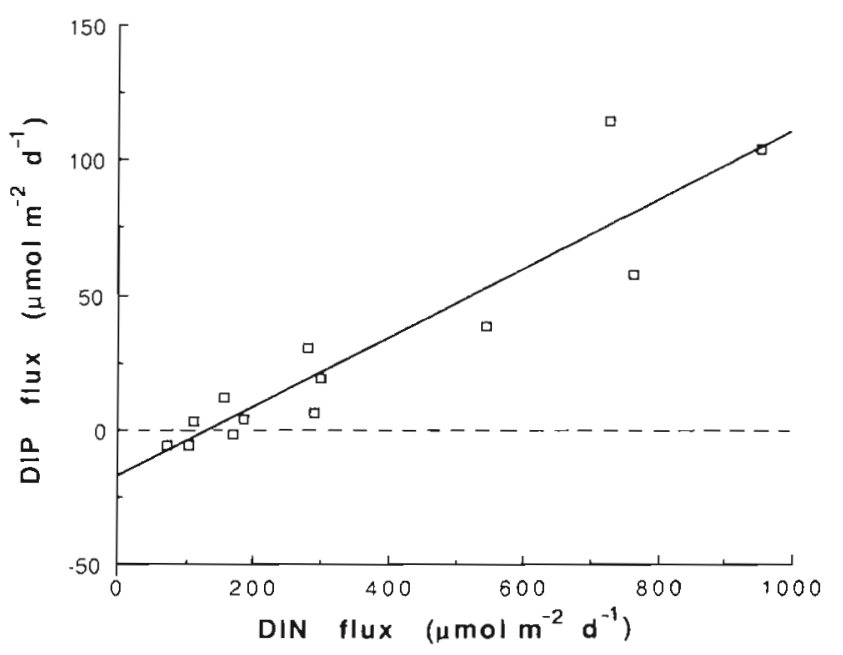

Fig. 4. Relation between sediment water fluxes of DIP $\left(\mathrm{PO}_{4}{ }^{3-}\right)$ and DIN $\left(\mathrm{NO}_{3}^{-}\right.$and $\left.\mathrm{NH}_{4}^{+}\right)$

that the nutrient fluxes are largely controlled by processes within the oxic layer and that anaerobic processes are relatively unimportant. Although the bacterial production measured in the $5 \mathrm{~mm}$ sediment surface layer does not represent the bacterial production in the oxic zone at all stations, it may exert a dominant influence on the sediment-water fluxes of inorganic nutrients. Benthic bacterial production (aerobic and anaerobic) has been found to decline rapidly with depth in the sediment, particularly in the

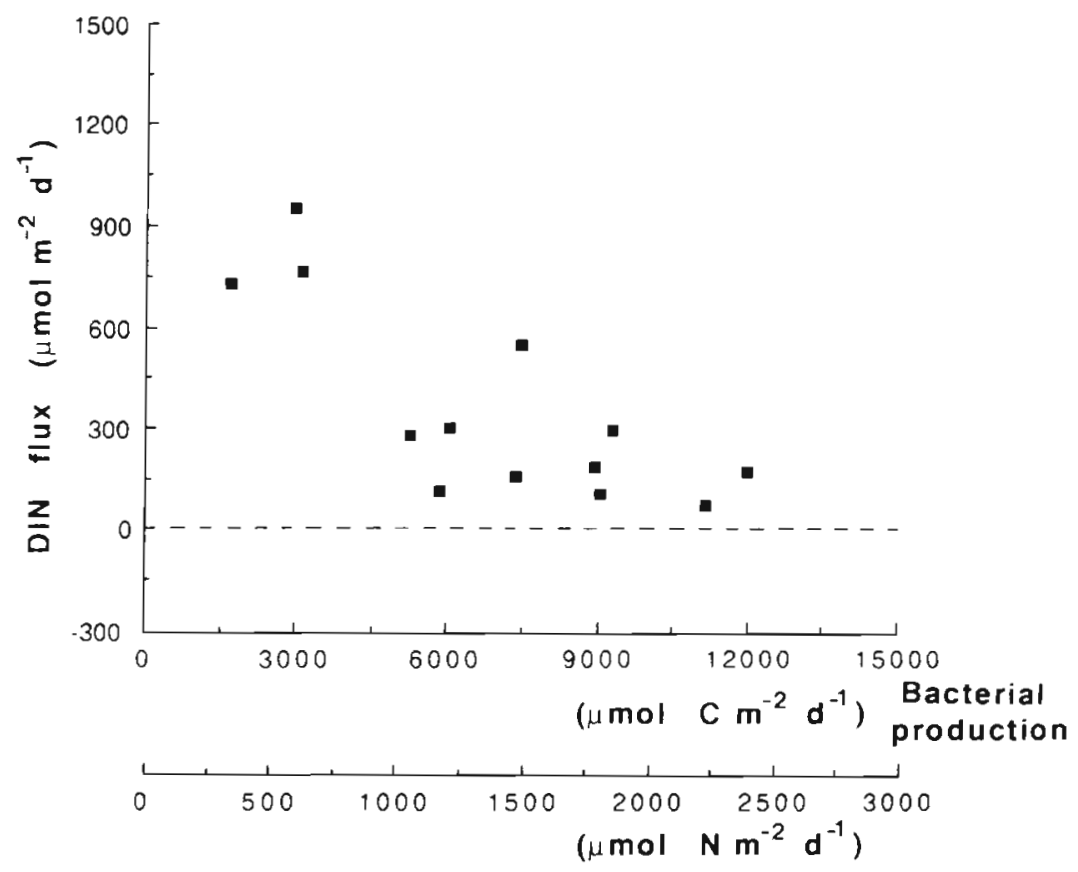

Fig. 5. Relation between bacterial $\mathrm{C}$ (and $\mathrm{N}$ ) assimilation in the $5 \mathrm{~mm}$ thick sediment surface layer and the sediment water exchange of DIN absence of burrowing activities (van Duyl et al. 1992b). Therefore, the contribution of activities of aerobic heterotrophic bacteria deeper down in the sediment to the sediment-water exchange was assumed to be low.

\section{Bacterial production and biomass: variation in space and time}

The spatial variation in bacterial production and biomass in the Dogger Bank region could not be explained by the spatial variation in sediment organic matter and grain size composition, including temperature. The range in sediment characteristics covered was apparently too small to reveal such relations (Yamamoto \& Lopez 1985, Cole et al. 1988). The absence of a relation between temperature and bacterial production indicates that the benthic system may be substrate-limited in the Dogger Bank region.

There are indications that short-term variability in labile organic matter may cause the variations in bacterial production and biomass. The summer range of bacterial production in the Dogger Bank region (20 to $143 \mathrm{mg} \mathrm{C} \mathrm{m} \mathrm{m}^{-2} \mathrm{~d}^{-1}$; 0 to $5 \mathrm{~mm}$ sediment surface layer) fell in the same range as the seasonal range in bacterial production reported for a sandy Dutch coastal station (29 to $158 \mathrm{mg} \mathrm{C} \mathrm{m}^{-2} \mathrm{~d}^{-1} ; 0$ to $5 \mathrm{~mm}$; van Duyl et al. 1992a) with the lowest values restricted to the winter period. This may imply that winter as well as summer conditions with respect to substrate availability occur in the Dogger Bank region in summer. It is known that the enhancement of heterotrophic microbial activity, in response to an organic matter input, returns to base rates in approximately 3 to $6 \mathrm{wk}$ (Graf et al. 1982, Graf et al. 1983, Meyer-Reil et al. 1983, van Duyl et al. 1992a, b). This may imply that stations with production rates similar to low winter values did not receive any substantial input in the last 3 to $6 \mathrm{wk}$, while the others did.

The range in bacterial biomass in the Dogger Bank region in summer also covered the annual range at the above mentioned station (van Duyl et al. 1992a). Variations in bacterial biomass, however, are not necessarily seasonal with enhanced values in summer (Meyer-Reil et al. 1980, Cammen 1982. Rublee 1982). Biomass in winter may be higher than in summer (Moriarty et al. 1990, van Duyl \& Kop 1990). Biomass variations within a particular sediment are due to temporary imbalances in 


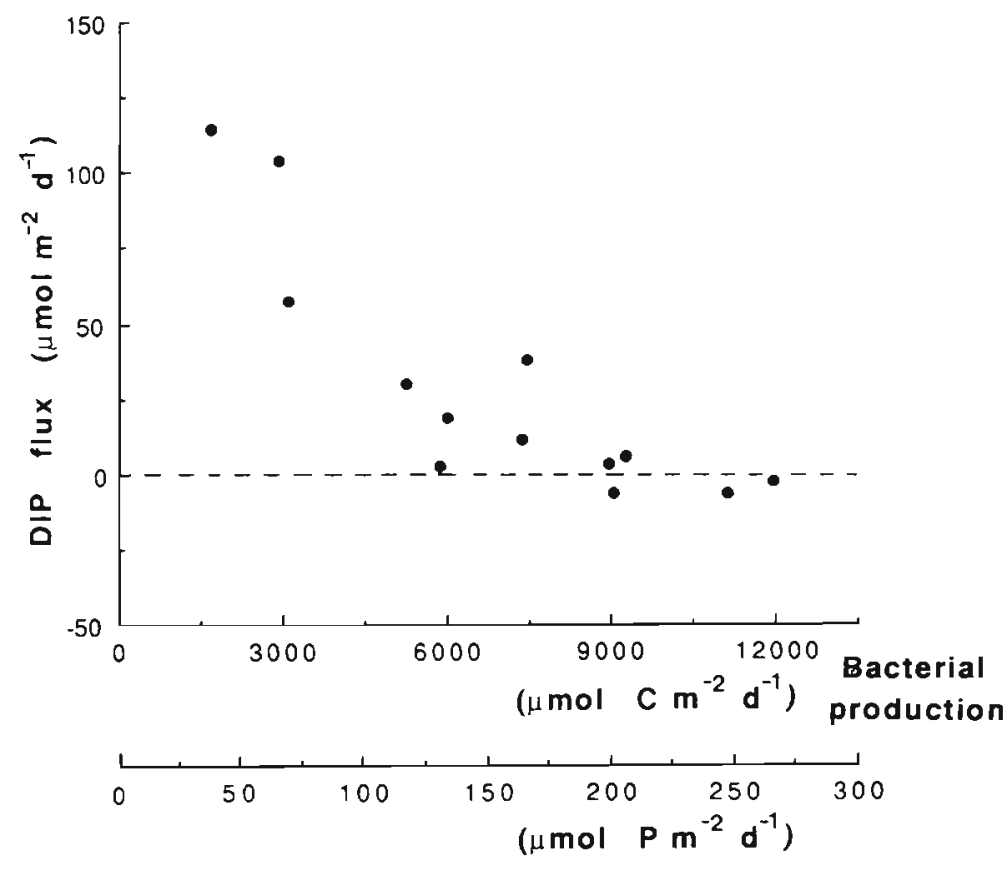

Fig. 6. Relation between bacterial $\mathrm{C}$ (and P) assimilation in the $5 \mathrm{~mm}$ thick sediment surface layer and the sediment water exchange of DIP production and mortality. Short-term variations in input of labile organic matter have been shown to induce synchronous variations in bacterial biomass and production (Moriarty \& Pollard 1982, Cammen \& Walker 1986, Meyer-Reil 1987, van Duyl et al. 1992b). The significant covariation between bacterial production and biomass suggests that such short-term events may indeed occur in the Dogger Bank region in summer. The available substrate dictates the variation in bacterial production, reflected by variations in biomass (bottom-up control). Top-down control by grazing on bacteria does not seem to be a forcing mechanism in sediments (e.g. Hansen et al. 1987, Kemp 1987, 1990, Alongi 1988, Hondeveld et al. 1992).

The process most likely to determine the variable input of labile organic matter in the Dogger Bank region will be sedimentation of organic material. The significant relation between bacterial biomass and sediment chlorophyll $a$ and pheo-

Table 4. Statistical evaluation (ANOVA) of influences of varying bacterial production (BP) and bacterial biomass (BB) on the sediment-water exchange rates of (a) DIN and (b) DIP respectively

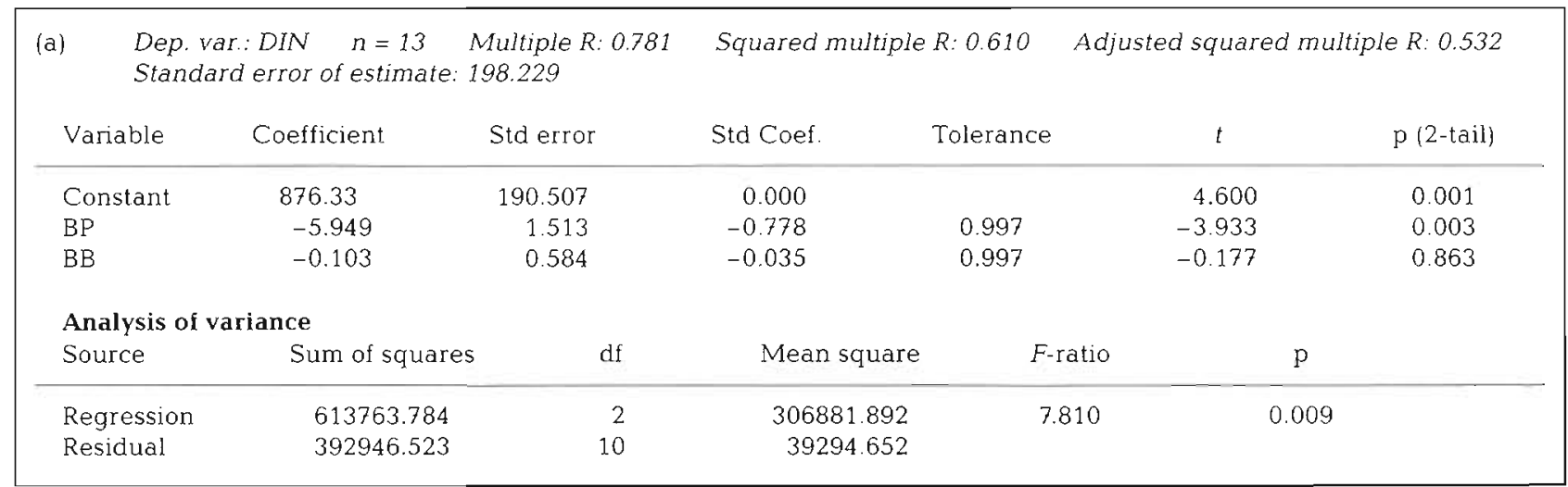

\begin{tabular}{|c|c|c|c|c|c|c|c|c|}
\hline \multirow[t]{2}{*}{ (b) } & \multicolumn{3}{|c|}{$\begin{array}{l}\text { Dep. var: DIP } \quad n=13 \quad \text { Multiple } R: 0.879 \\
\text { Standard error of estimate: } 21.074\end{array}$} & \multicolumn{2}{|c|}{ Squared multiple $R: 0.773$} & \multicolumn{3}{|c|}{ Adjusted squared multiple $R: 0.728$} \\
\hline & Variable & Coefficient & Std error & Std Coef. & \multicolumn{2}{|l|}{ Tolerance } & $t$ & $p(2-t a i l)$ \\
\hline $\mathrm{Col}$ & & 84.679 & & 0.000 & & & 4.181 & 0.002 \\
\hline $\mathrm{BP}$ & & -0.922 & & -0.865 & 0.997 & & -5.736 & 0.000 \\
\hline $\mathrm{BB}$ & & 0.086 & & 0.209 & 0.997 & & 1.384 & 0.197 \\
\hline \multicolumn{9}{|c|}{ Analysis of variance } \\
\hline \multicolumn{2}{|c|}{ Source } & Sum of $\mathrm{s}$ & $\mathrm{df}$ & Mean & \multicolumn{2}{|c|}{ F-ratio } & \multicolumn{2}{|c|}{$\mathrm{p}$} \\
\hline \multirow{2}{*}{\multicolumn{2}{|c|}{ Regression }} & 15132 & 2 & 756 & \multirow{2}{*}{\multicolumn{2}{|c|}{17.036}} & \multirow{2}{*}{\multicolumn{2}{|c|}{0.001}} \\
\hline & & 4441 & 10 & 44 & & & & \\
\hline
\end{tabular}


pigments, indicators for the presence of decaying algal material in the sediment, support this view. Substrate for bacteria from benthic primary production is highly unlikely, considering the depths of the stations. There was no relation between sediment chlorophyll $a$ and the depth of the water column.

In conclusion, variations in bacterial production and biomass were interpreted as a consequence of differences in availability of labile organic carbon, associated with the time passed since the latest sedimentation event. This means that interpretation of the variations in space might be considered as variation in time.

\section{Impact of bacterial variables on nutrient fluxes}

The significant negative relationships between bacterial production and nutrient fluxes do not support the view that benthic bacteria are important net mineralizers of organic matter. With increasing bacterial production the efflux of DIN and DIP out of the Dogger Bank sediments decreased instead of increased. The following explanations can be given:

(1) The DON and DOP effluxes will increase with increasing bacterial production in the sediment at the cost of DIN and DIP effluxes. In sediment microcosm experiments Hansen \& Blackburn (1991) observed a steep increase in the DON efflux in response to an algal substrate addition. In a comparable experiment Garber (1984) ascribed the initial increase in DON $(9 \%$ of the initial input) to hydrolysis, an artefact related to the pre-treatment of the algal input. The initial DON release after an organic input is probably determined by processes taking place in the algal detritus and not so much in the sediment surface layer. This seems an improbable explanation for the negative correlation between bacterial production in the sediment surface and the DIN efflux in the field.

(2) The $C: N: P$ ratio of both the organic substrate and bacteria may vary with substrate concentration and bacterial production respectively. The $\mathrm{N}$ and $\mathrm{P}$ content of the organic substrate may decrease at increasing bacterial production, or the $\mathrm{N}$ and $\mathrm{P}$ content of bacterial biomass may increase with increasing bacterial production. It has been shown that the $\mathrm{C}: \mathrm{N}: \mathrm{P}$ ratios of bacterial biomass can differ depending on the substrate C:N:P ratio (e.g. Goldman et al. 1987, Tezuka 1990). It is, however, improbable that the range in growth rates found in the Dogger Bank region are the result of the supply of different substrate $\mathrm{C}: \mathrm{N}: \mathrm{P}$ ratios (Balzer 1984, Klump \& Martens 1987). In addition, there are no indications that the $\mathrm{N}$ and $\mathrm{P}$ content of bacterial biomass increases only as a consequence of faster growth rates.
(3) Net increase in bacterial biomass by production coincides with a (temporary) immobilization of $\mathrm{N}$ and $\mathrm{P}$ in bacterial biomass. It assumes that changes in the net fluxes of $\mathrm{N}$ and $\mathrm{P}$ into bacterial biomass are large enough to be reflected in the sediment-water exchange of mineral nutrients. In aerobic surface sediments both $\mathrm{NH}_{4}{ }^{+}$and $\mathrm{PO}_{4}{ }^{3-}$ can be assimilated as a source of $\mathrm{N}$ and $\mathrm{P}$ by benthic heterotrophic bacteria (e.g. Blackburn \& Henriksen 1983, Gächter et al. 1988, Sumi \& Koike 1990). Based on C:N:P ratios of sedimentated organic matter and the high growth efficiencies of bacteria (e.g. Ducklow 1983, Moriarty et al. 1985) the available organic substrate apparently contains insufficient $\mathrm{N}$ and $\mathrm{P}$ for biomass production. Uptake of other sources of inorganic $N$ and $P$ is required to compensate for the apparent $\mathrm{N}$ and $\mathrm{P}$ shortage. However, the porewater concentrations of $\mathrm{N}$ and $\mathrm{P}$ in the Dogger Bank region did not change significantiy. Inorganic $\mathrm{N}$ and $\mathrm{P}$ may be quickly replenished in the porewater by regeneration and/or by diffusive transport. In case of a net increase in bacterial biomass, replenishment by diffusive transport (either from deeper down in the sediment or from the water column) may be the most important. The net uptake of $\mathrm{N}$ and $\mathrm{P}$ by bacteria in the $5 \mathrm{~mm}$ sediment surface layer apparently influences the size and possibly also the direction of the diffusive transport of DIN and DIP. Changes in the diffusive transport are subsequently reflected in the sediment-water exchange of DIN and DIP. This process may be the most plausible explanation for the negative relationships between bacterial production and DIN and DIP sediment-water fluxes.

The important question now is whether the increase in bacterial biomass is sufficient to explain the observed changes in DIN and DIP fluxes with increasing bacterial production. The time span over which the ranges in benthic bacterial production and biomass in the Dogger Bank region may have developed is unknown. The total response period of the benthic system after a sedimentation event is 3 to $6 \mathrm{wk}$, as mentioned above. Thus the initial period of increase in bacterial variables from base rates to maxima must fall within a shorter time span. Based on sediment boxcosm experiments with similar types of sediments it was demonstrated that $5 \mathrm{~d}$ after an algal input bacterial biomass and production reached their maximum values showing ranges which more than covered the ranges of these variables in the Dogger Bank region (Fig. 7) (van Duyl et al. 1992b). By assuming a similar time span (5 d) for the increase period of bacterial biomass and production in the Dogger Bank region, the increase in bacterial biomass $N$ and $P$ and the decrease in DIN and DIP were estimated. It appeared that the increase in bacterial biomass $N$ and $P$ was balanced by a decrease in the DIN and DIP fluxes 


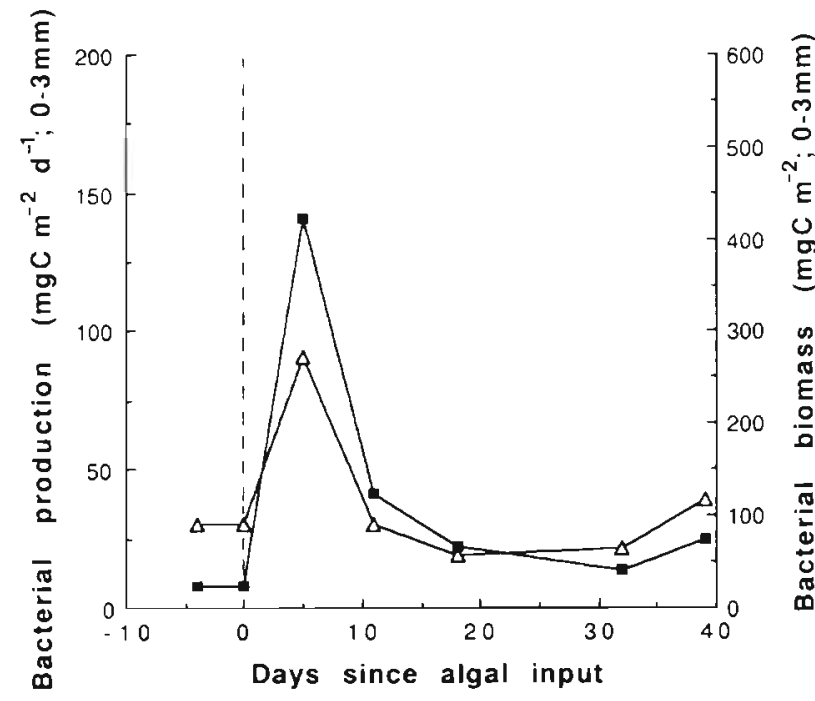

Fig. 7. Sediment boxcosm experiment. The response of benthic bacterial production (a) and biomass $(\Delta)$ to an algal input of Phaeocystis spp. (Fig. redrawn from van Duyl et al. 1992b). Manipulated sandy North Sea sediments, poor in organic matter, were incubated in round polypropylene containers $\left(31 \mathrm{~cm}\right.$ in diameter and $35 \mathrm{~cm}$ high) at $12^{\circ} \mathrm{C}$ in the dark and supplied with running aged seawater. After an acclimatization period of $5 \mathrm{wk}$ an input of thawed algal material (24 $\mathrm{g} \mathrm{C} \mathrm{m}^{-2}$, dominated by Phaeocystis spp.) was supplied and enticed after settlement a rapid response of the benthic bacterial biomass and the bacterial production in the $3 \mathrm{~mm}$ sediment surface layer. In $5 \mathrm{~d}$ a maximum for both variables was reached which was followed by a decline and a return to 'starvation values' In the first $5 \mathrm{~d}$ approximately 50 to $60 \%$ of the bacterial production was allocated to net increase of bacterial biomass

(Table 5). More than $70 \%$ of the biomass increase expressed in $\mathrm{N}$ and $\mathrm{P}$ is provided by the decrease in the DIN and DIP fluxes (Table 5). Apparently bacterial net sequestration of $\mathrm{N}$ and $\mathrm{P}$ more than accounts for the decreased flux.

The actual amount of organic matter required to yield such an increase in biomass $\left(121 \mathrm{mg} \mathrm{C} \mathrm{m}^{-2}\right.$ in the Dogger Bank) would be around $900 \mathrm{mg}$ organic $\mathrm{C} \mathrm{m}^{-2}$ (assuming a 50\% growth yield of the benthic bacteria; e.g. Monarty et al. 1985). Then $50 \%$ of the input ( $450 \mathrm{mg}$ C) will be respired, and $50 \%$ incorporated into bacterial biomass. Out of these $450 \mathrm{mg} \mathrm{C,} 121 \mathrm{mg} \mathrm{C} \mathrm{(27 \% )} \mathrm{were}$ allocated to biomass increase over $5 \mathrm{~d}$ (calculated from

Table 5. Comparison of DIN $\left(\mathrm{NO}_{3}{ }^{-}\right.$and $\left.\mathrm{NH}_{4}{ }^{+}\right)$and DIP $\left(\mathrm{PO}_{4}{ }^{3-}\right)$ flux decreases with bacterial biomass increases over a $5 \mathrm{~d}$ period

\begin{tabular}{|cccc|}
\hline & $\begin{array}{c}\text { Flux decrease } \\
\left(\mu \mathrm{mol} 5 \mathrm{~d}^{-1}\right)\end{array}$ & $\begin{array}{c}\text { Biomass increase } \\
\left(\mu \mathrm{mol} 5 \mathrm{~d}^{-1}\right)\end{array}$ & \% demand \\
\hline $\mathrm{N}$ & 1682 & 2270 & 74 \\
$\mathrm{P}$ & 193 & 196 & 98 \\
\hline
\end{tabular}

Fig. 3), leaving $73 \%$ (329 mg C) for mortality. This $73 \%$ was assumed to become available by recycling (Alongi 1989, Moriarty 1989). Novitsky (1986) showed that microbial detritus (dead bacteria) forms a labile component of the sediment, readily assimilable for bacteria. The rest ( 900 minus $329 \mathrm{mg} \mathrm{C} \mathrm{m}{ }^{-2}$ ) is required from other input sources such as sedimentation of organic matter. To compensate for the fact that only up to $30-50 \%$ of detrital algal material is labile and decomposable within days (Lancelot \& Billen 1985, Hansen \& Blackburn 1991, van Raaphorst et al. 1992) a total amount of ca $1100 \mathrm{mg} \mathrm{C} \mathrm{m}^{-2}$ is required from sources such as sedimentation of organic matter in a period of 5 d, i.e. $220 \mathrm{mg} \mathrm{C} \mathrm{m} \mathrm{m}^{-2} \mathrm{~d}^{-1}$.

The range of benthic oxygen consumption in the Dogger Bank region indicates that $\mathrm{C}$ oxidation is in the range 40 to $190 \mathrm{mg} \mathrm{C} \mathrm{m}^{-2} \mathrm{~d}^{-1}(\mathrm{RQ}=0.85$ according to Hargrave 1973) (van Raaphorst et al. 1990, Cramer 1991). If the high values (e.g. $190 \mathrm{mg} \mathrm{C} \mathrm{m}^{-2} \mathrm{~d}^{-1}$ ) continue for several consecutive days in the form of labile organic matter, the required carbon input may reach the sediment. This implies that mineralization and supply through deposition are almost in balance. Consequently, there seems to be no significant storage of organic matter in the Dogger Bank sediments in the summer months. There are no data available on sedimentation in the Dogger Bank region. Sedimentation in the Fladen Ground north of the Dogger Bank in summer amounted to as much as $45 \mathrm{mg} \mathrm{C} \mathrm{m}^{-2} \mathrm{~d}^{-1}$ with considerable day-to-day variations (Cadée 1986). There are reasons to assume that in the Dogger Bank region occasionally more material can settle. On both sides of the Dogger Bank fronts can develop in the water column during summer, when thermal stratification develops. Due to mixing of nutrient-rich bottom waters with nutrient-depleted surface waters algal blooms may develop in fronts (Braarud et al. 1953). Riegman et al. (1990) demonstrated such a mixing event during our expedition in the Dogger Bank region. Part of the organic material formed is assumed to settle in the Dogger Bank region proper. Assuming that such sedimentation events are intermittent and occur only locally in the region, a heterogeneous pattern of benthic bacterial production may be found in the region with bacterial production in different stages of response to a sedimentation event.

In conclusion, the organic matter input required for an increase in bacterial production and biomass in a time span of $5 \mathrm{~d}$ is not unreasonable. Based on this model we may conclude that benthic heterotrophic bacteria in the oxic layer of oligotrophic sandy sediments can control the sediment-water exchange of mineral nutrients in response to short-term sedimentation events. Moreover, heterotrophic benthic bacteria act as sinks for $\mathrm{N}$ and $\mathrm{P}$ under these conditions, only 
releasing $N$ and $P$ upon death. This temporary immobilization of $\mathrm{N}$ and $\mathrm{P}$ induces a time-lag between assimilation and release which may have consequences for the nutrient availability in the water column.

Acknowledgements. We are grateful to D. B. Nedwell for careful reading and constructive criticism of the manuscript. This is publication no. 52 of the project 'Applied Scientific Research, Netherlands Institute for Sea Research' (BEWON). The Window expedition was financially supported by the Netherlands Marine Research Foundation.

\section{LITERATURE CITED}

Alongi, D. A. (1988). Bacterial productivity and microbial biomass in tropical mangrove sediments. Microb. Ecol. 15: $59-79$

Alongi, D. A. (1989). The fate of bacterial biomass and production in marine benthic food chains. In: Hattori, $T$. Ishida, Y., Maruyama, Y., Morita, R. Y., Uchida, A. (eds.) Recent advances in microbial ecology. Japan Scientific Soc. Press, Tokyo, p. 355-359

Alongi, D. M., Hansen, R. B. (1985). Effect of detritus supply on trophic relationships within experimental benthic food webs. II. Microbial responses, fate and composition of decomposing detritus. J. exp. mar. Biol. Ecol. 88: 167-182

Azam, F., Fenchel, T., Field, J. G., Gray, J. S., Meyer-Reil, L. A., Thingstad, F. (1983). The ecological role of watercolumn microbes in the sea. Mar Ecol. Prog. Ser. 10: $257-263$

Balzer, W. (1984). Organic matter degradation and biogenic element cycling in a nearshore sediment (Kiel Bight). Limnol. Oceanogr. 29: 1231-1246

Bell, R. T (1986). Further verification of the isotope dilution approach for estimating the degree of participation of $\left[{ }^{3} \mathrm{H}\right]$ thymidine in DNA synthesis in studies of aquatic bacterial production. Appl. environ. Microbiol. 52: 1212-1214

Bender, M. L., Heggie, D. T. (1984). Fate of organic carbon reaching the deep sea floor: a status report. Geochim. Cosmochim. Acta 48: 977-986

Blackburn, T H.. (1988). Benthic mineralization and bacterial production. In: Blackburn, $\mathrm{T}$ H., Sorensen, J. (eds.) Nitrogen cycling in coastal marine environments. Wıley, New York, p. 175-190

Blackburn, T. H., Henriksen, K. (1983). Nitrogen cycling in different types of sediments from Danish waters. Limnol. Oceanogr. 28: 477-493

Bloem, J., Starink, M., Bär-Gilissen, M.-J., Cappenberg, T E. (1988). Protozoan grazing, bacterial activity, and mineralization in two-stage continuous cultures. Appl. environ Microbiol. 54: 3113-3121

Braarud, T., Ringdaal Gaalder, K., Grontved, J. (1953). The phytoplankton of the North Sea and adjacent waters in May 1948. J. Cons. int. Explor. Mer 13: 5-89

Bratbak, G. (1985). Bactenal biovolume and biomass estimations. Appl. environ. Microbiol. 49: 1488-1493

Bratbak, G. (1987). Carbon flow in an experimental microbial ecosystem. Mar. Ecol. Prog. Ser 36: 267-276

Bratbak, G., Dundas, I. (1984). Bacterial dry matter content and biomass estimations. Appl environ. Microbiol. 48 $755-757$

Cadée, G. C. (1986). Organic carbon in the water column and its sedimentation, Fladen Ground (North Sea), May 1983 Neth. J. Sea Res. 20: $347-358$
Cammen, L. M. (1982). Effect of particle size on organic content and microbial abundance within four marine sediments. Mar. Ecol. Prog. Ser. 9: 273-280

Cammen, L. M., Walker, J. A. (1986). The relationship between bacteria and micro-algae in the sediment of a Bay of Fundy mudflat. Estuar. coast. Shelf Sci. 22: $91-99$

Cole, J. J., Findlay, S., Pace, M. L. (1988). Bacterial production. in fresh and saltwater ecosystems: a cross-system overview. Mar. Ecol. Prog. Ser. 43: 1-10

Cramer, A. (1991). Benthic metabolic activity at frontal systems in the North Sea. Ph.D. State Univ. Groningen, Netherlands

Ducklow, H. W. (1983). The production and fate of bacteria in the oceans. BioSci. 33: 494-501

Froelich, P. N., Klinkhammer, G. P., Bender, M. L., Luedtke, N. A., Heath, G. R., Cullen, D., Dauphin, P., Hammond, D., Hartman, B., Maynard, V. (1979). Early oxidation of organic matter in pelagic sediments of the eastern equatorial Atlantic: suboxic diagenesis. Geochim. Cosmochim Acta 43: 1075-1090

Gächter, R, Meyer, J S., Mares, A. (1988). Contribution of bacteria to release and fixation of phosphorus in lake sediments. Limnol. Oceanogr. 33: 1542-1558

Garber, J. H. $(1984) .{ }^{15} \mathrm{~N}$ tracer study of the short-term fate of particulate organic nitrogen at the surface of coastal marine sediments. Mar. Ecol. Prog. Ser 16: 89-104

Goldman, J. C., Caron, D. A., Dennett, M. R. (1987). Regulation of gross growth efficiency and ammonium regeneration in bacteria by substrate $\mathrm{C}: \mathrm{N}$ ratio. Limnol. Oceanogr. 32: $1239-1252$

Graf, G., Bengtsson, W., Diesner, U., Schulz, R., Theede, H. (1982). Benthic response to sedimentation of a spring phytoplankton bloom: process and budget. Mar. Biol. 67 : $201-208$

Graf, G., Schulz, R., Peinert, R., Meyer-Reil, L.-A. (1983). Benthic response to sedimentation events during autumn to spring at a shallow-water station in the Western Kiel Bight. Mar. Biol. 77: 235-246

Hansen, J. A., Alongi, D. M., Moriarty, D. J. W., Pollard, P. C. (1987). The dynamics of benthic microbial communities at Davies Reef. central Great Barrier Reef. Coral Reefs 6: $63-70$

Hansen, L. S., Blackburn, T. H. (1991). Aerobic and anaerobic mineralization in marine sediment microcosms. Mar. Ecol. Prog. Ser. 75: 283-291

Hargrave, B. T. (1973). Coupling carbon flow through some pelagic and benthic communities. J. Fish Res. Bd Can. 35 . $1317-1326$

Helder, W., Vries, R. T P. (1979). An automatic phenolhypochlorite method for determination of ammonia in sea- and brackish waters. Neth. J. Sea Res. 13: 154-160

Henriksen, K., Kemp, W. M. (1988). Nitrification in estuarine and coastal marine sediments. In: Blackburn, $\mathrm{T} H$., Sorensen, $J$. (eds.) Nitrogen cycling in coastal marine environments. Wiley, New York, p. 207-249

Holm-Hansen, O., Lorenzen, C. J., Holmes, R. W., Strickland, J D. H. (1965). Fluorometric determinations of chlorophyll. J. Cons. int. Explor. Mer 30: 3-15

Hondeveld, B. J. M., Bak, R. P. M., van Duyl, F. C. (1992). Bacterivory by heterotrophic nanoflagellates in marine sediments measured by uptake of fluorescently labeled bacteria. Mar. Ecol. Prog. Ser. 89: 63.71

Jurgens, K., Gude, H. (1990). Incorporation and release of phosphorus by planktonic bacteria and phagotrophic flagellates. Mar Ecol. Prog. Ser. 59: 271-284

Kemp, P. (1987). Potential impact on bavcteria of grazing by a macrofaunal deposit-feeder, and the fate of bacterial 
production. Mar. Ecol. Prog. Ser. 36: 151-161

Kemp, P. F. (1990). The fate of benthic bacterial production. Aquat. Sci. 2: 109-124

Klump, J. V., Martens, C. S. (1987). Biogeochemical cycling in an organic-rich coastal marine basin. 5. Sedimentary nitrogen and phosphorus budgets based upon kinetic models, mass balances, and the storchiometry of nutrient regeneration. Geochim. Cosmochim. Acta 51; 1161-1173

Lancelot, C., Billen, G. (1985). Carbon-nitrogen relationships in nutrient metabolism of coastal marine ecosystems. Adv. aquat. Microbiol. 3: 263-321

Martinussen, I., Thingstad, T. F. (1987). Utilization of N, P and organic $\mathrm{C}$ by heterotrophic bacteria. II. Comparison of experiments and a mathematical model. Mar. Ecol. Prog. Ser. 37: 285-293

Meyer-Reil, L.-A. (1983). Benthic response to sedimentation events during autumn to spring at a shallow water station in the western Kiel Bight. II. Analysis of benthic bacterial production. Mar. Biol. 77: 247-256

Meyer-Reil, L.-A. (1987). Seasonal and spatial distribution of extracellular enzymatic activities and microbial incorporation of dissolved organic substrates in marine sediments. Appl. environ. Microbiol. 53: 1748-1755

Meyer-Reil, L.-A., Bölter, M., Dawson, R., Liebezeit, G., Szwerinski. H., Wolter, K. (1980). Interrelationships between microbiological and chemical parameters of sandy beach sediments, a summer aspect. Appl. environ. Microbiol. 39: 797-802

Michel, P. H., Bloem, J. (1993). Conversion factors for estimation of cell production rates of soil bacteria from $\left[{ }^{3} \mathrm{H}\right]$ thymidine and $\left[{ }^{3} \mathrm{H}\right]$ leucine incorporation. Soil Biol Biochem. 25: $943-950$

Moriarty, D. J. W. (1988). Accurate conversion factors for calculating bacterial growth rates from thymidine incorporation into DNA: elusive or illusive? Arch. Hydrobiol. Beih. Ergebn. Limnol. 31: 211-217

Moriarty, D. J. W. (1989). Relationships of bacterial biomass and production to primary production in marine sediments. In: Hattori, T., Ishida, Y., Maruyama, Y., Morita, R. Y., Uchida, A. (eds.) Recent advances in microbial ecology. Japan Scientific Soc. Press, Tokyo, p. 349-354

Moriarty, D. J W. (1990). Techniques for estimating bacterial growth rates and production of biomass in aquatic environments. In: Grigorova, R., Norris, J. K. (eds.) Methods in microbiology, Vol. 22. Academic Press, London, p. 211-234

Moriarty, D. J. W., Pollard, P. C. (1982). Diel variation of bacterial productivity in seagrass (Zostera capricorni) beds measured by rate of thymidine incorporation into DNA. Mar. Biol. 72: 165-173

Moriarty, D. J. W., Pollard, P. C. (1990). Effects of radioactive labelling of macromolecules, disturbance of bacteria and adsorption of thymidine to sediment on the determination of bacterial growth rates in sediment with tritiated thymidine. J. microbiol. Meth. 11: 127-139

Moriarty, D. J. W., Pollard, P. C., Hunt, W. G., Moriarty, C. M., Wassenberg, T J. (1985). Productivity of bacteria and microalgae and the effect of grazing by holothurians in sediments on a coral reef flat. Mar. Biol. 85: 293-300

Moriarty, D. J. W., Roberts, D. G., Pollard, P. C. (1990). Primary and bacterial productivity of tropical seagrass communities in the Gulf of Carpentaria, Australia. Mar Ecol. Prog. Ser. 61: 145-157

Novitsky, I. A. (1986). Degradation of dead microbial bio- mass in a marine sediment. Appl. environ. Microbiol. 52 $504-509$

Reineck, H. E. (1963). Der Kastengreifer. Natur u. Museum 93: $102-108$

Riegman, R. Malschaert, J. P. F., Colijn, F. (1990). Primary production of phytoplankton at a frontal zone located at the northern slope of the Doggerbank (North Sea). Mar. Biol. 105: 329-336

Rublee, P. A. (1982). Seasonal distribution of bacteria in salt marsh sediments in North Carolina. Estuar. coast. Shelf Sci. 15: 67-74

Rutgers van der Loeff, M. M. (1980). Nutrients in the interstitial waters of the southern Bight of the North Sea. Neth. J. Sea Res. 14: 14-17

Saager, P. M., Baar, H. J. W. d., Kloosterhuis, H. T., Raaphorst, W. van (1989). Trace element geochemistry of sandy sediments and overlying waters at the Dogger Bank, North Sea. NIOZ-report, Neth. Inst. Sea Res., Texel, 8, p. 1-72

Simon, N. S. (1988). Nitrogen cycling between sediment and the shallow-water column in the transition zone of the Potomac River and estuary. I. Nitrate and ammonium fluxes. Estuar. coast. Shelf Sci. 26: 483-497

Strickland, J. D., Parsons, T R. (1972). A practical handbook of seawater analysis, 2nd edn. Bull. Fish. Res. Bd Can. 167. $1-311$

Sumi, T., Koike, 1. (1990). Estimation of ammonification and ammonium assimilation in surficial coastal and estuarine sediments. Limnol. Oceanogr. 35: 270-286

Tezuka, Y (1990). Bacterial regeneration of ammonium and phosphate as affected by carbon:nitrogen:phosphorus ratio of organic substrates. Microb. Ecol.19: 227-238

Tupas, L., Koike, I. (1990). Amino acid and ammonium utilization by heterotrophic marine bacteria grown in enriched seawater. Limnol. Oceanogr. 35: 1145-1155

Tupas, L., Koike, I. (1991). Simultaneous uptake and regeneration of ammonium by mixed assemblages of heterotrophic marine bacteria. Mar. Ecol. Prog. Ser 70: 273-282

van Duyl, F. C., Bak, R. P. M., Kop, A. J., Nieuwland, G., Berghuis, E. M., Kok, A. (1992a). Mesocosm experiments. mimicking seasonal developments of microbial variables in North Sea sediments. Hydrobiologia 235/236: 267-281

van Duyl, F. C., Kop, A. J. (1990). Seasonal patterns of bacterial production and biomass in intertidal sediments of the western Dutch Wadden Sea. Mar Ecol. Prog. Ser. 59 249-261

van Duyl, F. C., Kop, A. J., Kok, A., Sandee, A. J. J. (1992b). The impact of organic matter and macrozoobenthos on bacterial and oxygen variables in marine sediment boxcosms. Neth. J. Sea Res. 29: 343-355

van Raaphorst, W., Kloosterhuis, H. T., Bakker, K. J. M. (1990). Nutrient early diagenesis in the sandy sediments of the Dogger Bank area, North Sea; pore water results. Neth. J. Sea Res. 26: 25-52

van Raaphorst, W., Kloosterhuis, H. T., Berghuis, E. M., Gieles, A. J. M., Malschaert, J. F. P., van Noort, G. J. (1992). Nitrogen cycling in two types of sediments of the southern North Sea (Frisian Front, Broad Fourteens): field data and mesocosm results. Neth. J. Sea Res. 28: 293-316

Wheeler, P. A., Kirchman, D. L. (1986). Utilization of inorganic nitrogen by bacteria in marine systems. Limnol. Oceanogr 31: 998-1009

Yamamoto, N., Lopez, G. (1985). Bacterial abundance in relation to surface area and organic content of marine sediments. J. exp. mar. Biol. Ecol. 90: 209-220 